\title{
Twenty Six
}

National Cancer Institute

\section{Source}

National Cancer Institute. Twenty Six. NCI Thesaurus. Code C126886.

A natural number greater than twenty-five and less than twenty-seven and the quantity that it denotes. 